\title{
低温食塩水中におけるアルミニウム合金の腐食挙動*
}

\author{
舛形 剛**, 藤原和雄 ${ }^{* *}$, 高谷泰之***, 新開光一 ${ }^{\dagger}$, 林 浩一 $^{\dagger}$ \\ ** 株式会社コベルコ科研 \\ *** 兵庫県立工業技術センター \\ †株式会社神戸製鋼所
}

\section{Corrosion Behavior of Aluminum Alloy in Sodium Chloride Solution at Low Temperature*}

\author{
Tsuyoshi Masugata**, Kazuo Fujiwara**, Yasuyuki Takatani***, Koichi Shinkai ${ }^{\dagger}$ \\ and Koichi Hayashi ${ }^{\dagger}$ \\ ** Kobelco Research Institute, Inc. \\ *** Hyogo Prefectural Institute of Industrial Research \\ ${ }^{\dagger}$ Kobe Steel, Ltd
}

\begin{abstract}
A heat exchanger for vaporizing liquefied natural gas (LNG) is made of aluminum alloy tubes, and the way of protecting the tubes from corrosion in sea-water is to form a sacrificial anode layer by thermal-spray coating of $\mathrm{Al}-\mathrm{Zn}$ alloy on aluminum alloy tubes. However, corrosion damage has been sometimes found in the lower part of heat exchangers exposed to low temperature of freezing sea-water. The purpose of this study is to investigate the corrosion behavior of A3003 aluminum alloy in freezing sodium chloride solution and to examine a possibility of electrochemical impedance spectroscopy for monitoring of the corrosion process of heat exchanger. The aluminum alloy corrodes at $253 \mathrm{~K}$ in freezing sodium chloride solution. The characteristic of polarization was a cathodic control at this temperature. The corrosion rate obtained by the measurement of electrochemical impedance spectroscopy didn't change with immersion time, corresponding with the corrosion rate obtained by the weight loss method. It was found that this technique is a convenient tool for monitoring of the corrosion processes of heat exchanger in freezing sea-water.
\end{abstract}

Key words: Al alloy, liquefied natural gas, freezing sodium chloride solution, polarization, ac-impedance spectroscopy, corrosion, monitoring

\section{1.緒言}

液化天然ガス（以下 LNG と記す）の気化を目的とす る縦型熱交換器 (Open Rack Vaporizer ; ORV) の伝 熱管母材には，A 5083や A 3003 などのアルミニウム合 金が使用され，加熱媒体として海水が用いられてい $3^{11,2)}$ 。現在, 海水との接触による腐食防止手段として, 電気化学的にこれらの合金よりも卑な金属（Al-Zn）を

* 第 43 回腐食防食討論会 (大阪, 1996 年) で発表

** 丁651-0072 神戸市中央区脇浜町1-5-8(1-5-8, Wakihama-cho, Chuo-ku, Kobe, 651-0072 Japan)

*** 个654-0037 神戸市須磨区行平町 3-1-12 (3-1-12, Yukihira-cho, Suma-ku, Kobe, 654-0037 Japan)

+ T676-0008 高砂市荒井町新浜 2-3-1 (2-3-1, Shinhama, Arai-cho, Takasago, 676-0008 Japan)
伝熱管表面に溶射し，犠牲陽極層を形成する ${ }^{3)}$ 方法が採 用されている。

しかし, 特に熱交換器下部では海水という腐食環境に さらされているのみならず, 海水の落下により伝熱管表 面は高流速を受けていることから，この部位では溶射皮 膜や母材の損傷が認められる場合がある。著者 ${ }^{4), 5)}$ は 回転電極試験を用いて, 流速下の腐食挙動を電気化学的 に検討した結果, その腐食反応が溶存酸素によって律速 されることや腐食モニタリング方法として交流インピー ダンス法が有用な方法であることを見い出した。

一方, 実際の熱交換器下部のアルミニウム合金表面 は, LNGによって, 凍結から常温までの低温海水とい う腐食環境にもさらされている。しかし,このような凍 
結環境下におけるアルミニウム合金の腐食挙動に関する 報告はほとんど見当たらない。

そこで, 本研究では, 低温, 特に凍結状態での食塩水 環境下におけるアルミニウム合金の腐食挙動を調べると ともに，実機での腐食損傷を予知できる手法として交流 インピーダンス法 ${ }^{6)}$, 7) の可能性を検討したので報告す る。また, 凍結状態における電気化学測定のための参照 電極の検討も行ったので合わせて報告する。

\section{2. 参照電極の安定性の検討}

本実験では $253 \mathrm{~K}$ という試験溶液が涷結する温度域 で電気化学測定を行う必要があるため, 市販の参照電極 を内部参照電極として用いると参照電極内の溶液である 飽和 $\mathrm{KCl}$ 水溶液が凍結し, 液抵抗が大きくなり電位測 定が不可能になることや，ガラス製セルが破損するとい う問題が生じる。これらのことから市販の参照電極を内 部参照電極として使用することは好ましくない。

そこで, 内部参照電極として, $\mathrm{Ag}$ 線上に電解により $\mathrm{AgCl}$ を析出させた $\mathrm{Ag} / \mathrm{AgCl}$ 電極 (以下電解 $\mathrm{Ag}$ / $\mathrm{AgCl}$ 電極と記す）および溶融した $\mathrm{AgCl}$ を $\mathrm{Ag}$ 線に溶 着させた $\mathrm{Ag} / \mathrm{AgCl}$ 電極（以下溶融 $\mathrm{Ag} / \mathrm{AgCl}$ 電極之 記す）の 2 種類を作成した。この製作した電極がこの温 度域で内部参照電極として用いることが可能であるか否 かを検討するために, 市販の $\mathrm{Ag} / \mathrm{AgCl}$ 電極（飽和 $\mathrm{KCl}$ 水溶液, $298 \mathrm{~K}$, 東亜電波製)を外部基準電極とし, 製作した $\mathrm{Ag} / \mathrm{AgCl}$ 電極の温度依存性を調べた。

Fig. 1 に各参照電極の温度依存性の結果を示す。

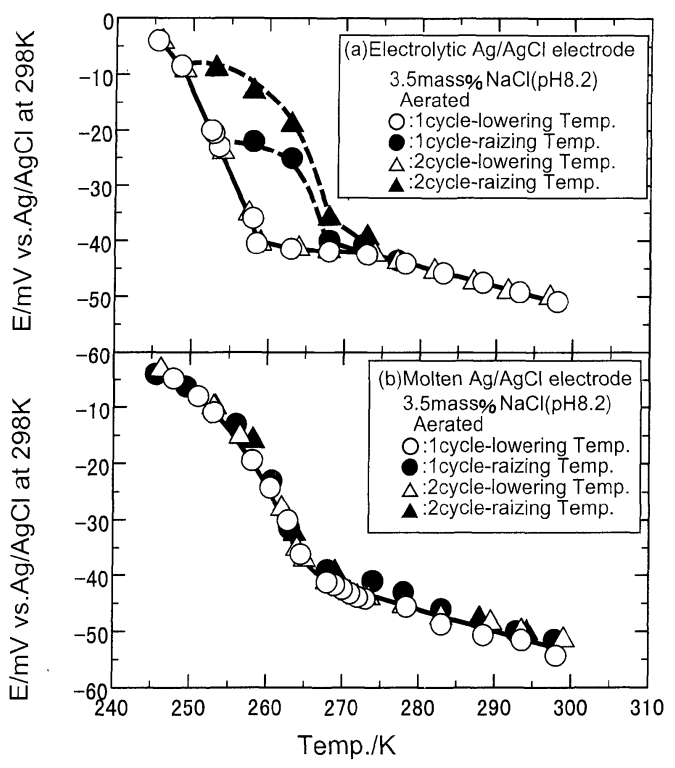

Fig. 1 Hysteresis curves of potential and temperature in $\mathrm{Ag} / \mathrm{AgCl}$ elctrode to be made.
溶液の凍結は $265 \mathrm{~K}$ 以下で生じるが, 製作した電極 のいずれの場合でも，ガラス製細管で短絡した外部 $\mathrm{Ag} / \mathrm{AgCl}$ 参照電極との電位差測定は約 $243 \mathrm{~K}$ まで可能 であった。それ以下の温度域では, 細管内の抵抗が大き くなり，電位差測定は不可能となった。

まず, 電解 $\mathrm{Ag} / \mathrm{AgCl}$ 電極の場合 (Fig. 1 (a)), 298 $\mathrm{K}$ から $273 \mathrm{~K}$ では温度低下にともなって+0.35 mV の 直線的な電位差の変化を示し, $273 \mathrm{~K}$ から $263 \mathrm{~K}$ では一 定值を示し, $258 \mathrm{~K}$ から $248 \mathrm{~K}$ まで $+31 \mathrm{mV}$ の急激な 変化を示した。逆に温度上昇にともなう電位差の変化は $273 \mathrm{~K}$ までは冷却過程と一致しないが，273 K になると 冷却過程時の電位差変化とよく一致した。再び, $298 \mathrm{~K}$ から再冷却再加熱すると電位差の変化は初回之同様の七 ステリシス曲線を示し，この $298 \mathrm{~K}$ から $243 \mathrm{~K}$ までの 電位差の変化は約 $45 \mathrm{mV}$ であった。

次に, 溶融 $\mathrm{Ag} / \mathrm{AgCl}$ 電極の場合 (Fig. 1 (b)), 電 解 $\mathrm{Ag} / \mathrm{AgCl}$ 電極のようなヒステリシス曲線とはなら ず, $298 \mathrm{~K}$ から $243 \mathrm{~K}$ の温度範囲では電位差の変化幅は $50 \mathrm{mV}$ とやや大きかったものの, 電位差の変化曲線は 冷却, 昇温, 再冷却および再昇温において, 同じ軌道を たどり再現性がよかった。以上のことからこの溶融 $\mathrm{Ag} / \mathrm{AgCl}$ 電極の方が内部参照電極として使用可能であ ることが確認された。

\section{3. 実験方法}

\section{1 供 試 材}

Fig. 2 に各試験用の試料形状を示す。

供試材には Al-Mn 系のアルミニウム合金 A 3003 (化 学組成 (mass\%) : Fe 0.47, Si 0.06, Cu 0.13, Mn 0.19，Zn 0.01）を用いた。

腐食試験用試料には圧延した板材 $\left(3 \mathrm{~mm}^{\mathrm{t}} \times 20 \mathrm{~mm}^{\mathrm{w}}\right.$ $\left.\times 100 \mathrm{~mm}^{1}\right)$ を用い, アルミナグリッドにてブラスト 処理した後, 乾燥空気で洗浄後秤量を行った。

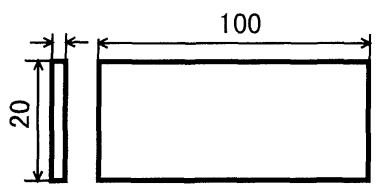

(a) for corrosion tests

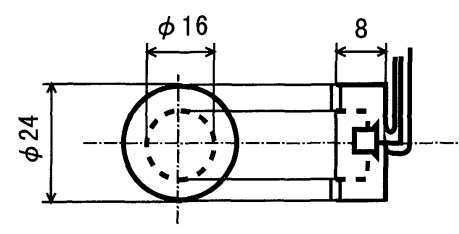

(b) for electrochemical tests

Fig. 2 Illustration of specimens. 
電気化学試験用試料には引抜き加工した棒状素材から 機械加工により製作した，ネジ穴部のある円筒状試料 $\left(16 \mathrm{~mm}^{\phi} \times 8 \mathrm{~mm}^{\mathrm{b}}\right)$ を用いた。この試料の裏面にボル 卜を通して銅線と接続しエポキシ樹脂に埋め込み, 試料 表面を $\mathrm{SiC}$ 研磨紙（\#600）で研磨, 水洗脱脂後見かけ の電極面積 $\left(1.0 \times 10^{-4} \mathrm{~m}^{2}\right)$ を残してシリコン樹脂で 被覆した。この試料を 24 時間デシケータ内にて保管し た後, 試験に供した。

\section{2 試 験 溶 液}

試験溶液には, 特級試薬 $\mathrm{NaCl}$ をイオン交換水で溶解 し，ホウ酸 $-\mathrm{NaOH}$ 緩衝液で $\mathrm{pH}$ を 8.2 に調整した 3.5 mass \% NaCl 水溶液を用いた。試験溶液は $\mathrm{NaOH}$ を 通した空気を吹き込み空気飽和とした。試験溶液の容量 は $1 \mathrm{dm}^{3}$ とした。試験温度は 303 から $253 \mathrm{~K}$ である。

\section{3 試 験方法}

腐食試験は試料を試験溶液に一定期間浸漬し，腐食質 量減を評価した。腐食質量減は腐食生成物を除去した後 の試料の質量を測定し, 浸漬試験前との質量差から求め た。なお, 腐食生成物除去方法は, 試験溶液から取り出 した試料を水洗した後, クロム酸-リン酸水溶液に浸漬 する方法を用いた。

電気化学試験は, 分極曲線測定と交流インピーダンス 測定の 2 通りを行った。

まず, 分極曲線測定は試料を一定期間浸漬した後, 試 験溶液が凍結する場合はそのままの状態で, 凍結しない 場合は試料を新しい空気飽和状態の試駼溶液中に移し替 え, 腐食電位からアノードおよびカソード方向に 0.2 $\mathrm{mV} \cdot \mathrm{s}^{-1}$ の電位掃引速度で分極し分極曲線を求めた。 なお，アノードおよびカソード分極曲線はそれぞれ別の 試料を用いて求め, 分極電位はカレント・インターラプ 卜法により IR 補正を行った。試験装置は EG＆G プリ ストンアプライド社製ポテンショスタット（M 273 A型） を用いた。

次に, 交流インピーダンス測定は三電極式セルを用 い, 浸漬試験中試料は取り替えずに所定の間隔で測定を 行った。測定は試料の腐食電位における印加交流電圧を $5 \mathrm{mV}$ とし, $1 \mathrm{mHz} \sim 100 \mathrm{kHz}$ の周波数範囲で行った。 試験装置は, ソーラトロン社製周波数応答解析装置 (FRA，SI 1260型) を用いた。すべての電気化学試験 は白金を対極とし,また, 溶融 $\mathrm{Ag} / \mathrm{AgCl}$ 電極を内部参 照電極として用いた。なお, 本報告中の電位は測定した 温度における飽和 $\mathrm{KCl}$ の $\mathrm{Ag} / \mathrm{AgCl}$ 電極基準で表示し た。いずれの試験も 303 から $253 \mathrm{~K}$ の温度域で行った。

\section{4. 実験結果および考察}

\section{1 腐食質量減の経時変化}

各温度 $303 ， 293 ， 278 ， 273 ， 263$ および $253 \mathrm{~K}$ におけ
る $3.5 \mathrm{mass} \% \mathrm{NaCl}$ 水溶液中に浸漬したアルミニウム 合金の腐食質量減の経時変化を Fig. 3 に示す。

常温付近である 303 および $293 \mathrm{~K}$ では浸漬開始から 7 日までの浸漬初期は腐食質量減は大きくなったが，そ の後, 腐食質量減の增加傾向は小さくなり, 腐食が抑制 されていることがわかる。常温以下の 283 および $273 \mathrm{~K}$ では, 浸漬開始から 7 日までの浸漬初期は腐食質量減が 大きく, それ以後は腐食質量減は一定速度で増加してい ることがわかる。また, 試験溶液が涷結する温度域であ る 263 および $253 \mathrm{~K}$ では, 腐食質量減は他の試験温度 と比較して少なく（例えば $303 \mathrm{~K}$ の場合の約 1 桁低い 值), 浸漬期間中にその増加傾向は観察されなかった。

したがって, 試験温度によって腐食質量減の経時変化 の傾向が 3 種類に分類され，その平均腐食速度をそれぞ れ計算すると, $293 \mathrm{~K}$ では $\Delta W=4.70 \times 10^{-1} \mathrm{~g} \cdot \mathrm{m}^{-2} \mathrm{~d}^{-1}$, $273 \mathrm{~K}$ では $\Delta W=1.30 \times 10^{-1} \mathrm{~g} \cdot \mathrm{m}^{-2} \mathrm{~d}^{-1}$ および $253 \mathrm{~K}$ では $\Delta W=2.48 \times 10^{-2} \mathrm{~g} \cdot \mathrm{m}^{-2} \mathrm{~d}^{-1}$ となった。

そこで, 腐食質量減の経時変化の挙動の異なる温度域 での腐食挙動を検討するために，293，273 および $253 \mathrm{~K}$ における電気化学試験を実施した。

\section{2 分極特性の経時変化}

各温度 293, 273 および $253 \mathrm{~K}$ における 3.5 mass \% $\mathrm{NaCl}$ 水溶液中に浸漬したアルミニウム合金の分極特性 の経時変化を Fig. 4, 5 および 6 に示す。なお， $253 \mathrm{~K}$ 浸漬直後の分極曲線測定は試験溶液が凍結するため, 試 験溶液が完全に凍結した $86.4 \mathrm{ks}$ 経過後の測定結果であ る。

まず, 各試験温度における浸漬直後のアノード分極曲 線に関して, 試験溶液が凍結しない 293 および $273 \mathrm{~K}$ では腐食電位から急激にアノード電流密度は増加する が, 温度が低下すると電流密度の增加が抑制される傾向 があり, $253 \mathrm{~K}$ では, 腐食電位からの電流密度増加がさ

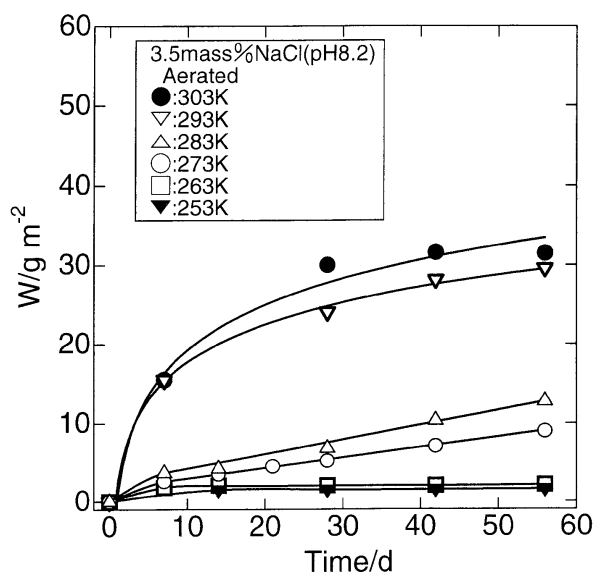

Fig. 3 Time variation of weight loss. 


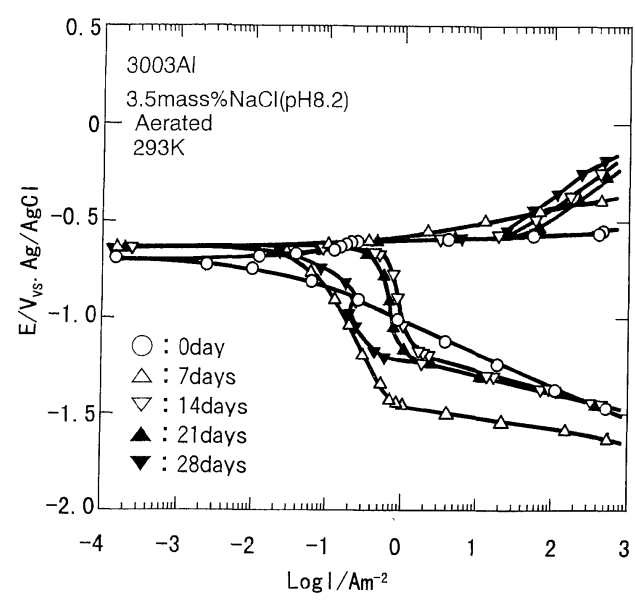

Fig. 4 Effect of immersion time on polarization curve of $\mathrm{A} 3003$ in aerated 3.5 mass $\% \mathrm{NaCl}$ $(\mathrm{pH} 8.2)$ at $293 \mathrm{~K}$.

らに緩やかとなった。カソード分極曲線は 293 および $273 \mathrm{~K}$ では腐食電位からカソード電流密度が急激に増加 しているが, $273 \mathrm{~K}$ では溶存酸素の拡散限界電流と考え られる停滞電流が現れ, 約 $1.4 \mathrm{~V}$ (vs. $\mathrm{Ag} / \mathrm{AgCl}$ ) 以 降から水素の還元反応にともなう電流密度の増加が観察 された。253Kでは, カソード電流密度が減少し腐食電 位から約 $1.4 \mathrm{~V}$ の範囲では $2 \times 10^{-3} \mathrm{~A} \cdot \mathrm{m}^{-2}$ の停滞電流 が現れ, 約 $1.4 \mathrm{~V}$ 以降から水素発生反応にともなう電 流密度の増加が観察された。

次に, 各温度における分極特性の経時変化に関して、 試験温度 $293 \mathrm{~K}$ （Fig. 4) では, 浸漬直後の腐食電位は $-0.7 \mathrm{~V}$ にあるが 7 日以上浸漬すると貴側に移行し $0.64 \mathrm{~V}$ で安定となる。すなわち, 大気酸化皮膜から水 酸化皮膜に变化したため, 電位が移行したものと考えら れる。アノード分極曲線は腐食電位から急激に増加し, 浸漬時間にともなう変化は認められなかった。一方, 力 ソード分極曲線は浸漬直後では腐食電位から緩やかに増 加するが 7 日以上浸漬した場合では腐食電位から-1.25 $\mathrm{V}$, あるいは-1.5V の範囲に停滞電流が現れ, それ以 降の電位では水素還元反応にともなう電流密度増加が観 察される。停滞電流は 14 21 日間で最大值の約 $1 \times 10^{0}$ $\mathrm{A} \cdot \mathrm{m}^{-2}$ を示し, 28 日後では減少し, 約 $2 \times 10^{-1} \mathrm{~A}$ ・ $\mathrm{m}^{-2}$ を示した。

試験温度 $273 \mathrm{~K}$ (Fig. 5 ) では, 腐食電位は $-0.6 \mathrm{~V}$ 付近と一定であり浸漬期間中, 变化は認められなかっ た。アノード分極曲線は腐食電位から急激に増加する が, 浸漬時間の経過にともないその電流密度の増加傾向 が緩やかとなった。カソード分極曲線は浸漬直後では腐 食電位から緩やかに増加しているが，7 日後以降では腐 食電位から約 $1.4 \mathrm{~V}$ までは停滞電流が現れ, それ以降

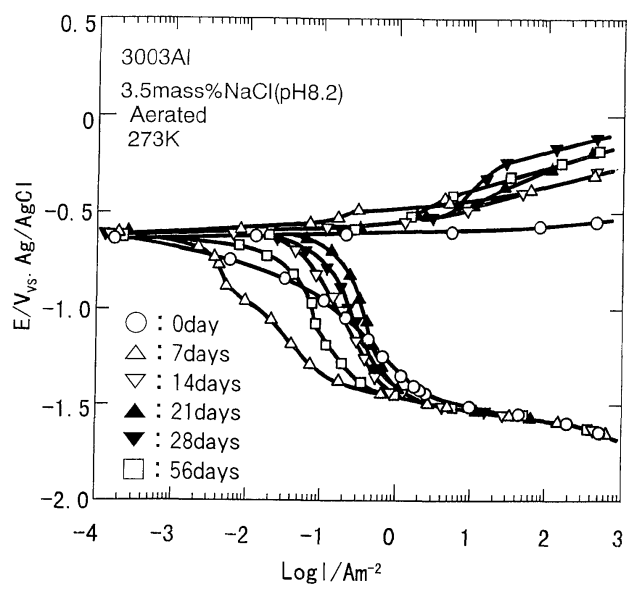

Fig. 5 Effect of immersion time on polarization curve of $\mathrm{A} 3003$ in aerated 3.5 mass $\% \mathrm{NaCl}$ $(\mathrm{pH} 8.2)$ at $273 \mathrm{~K}$.

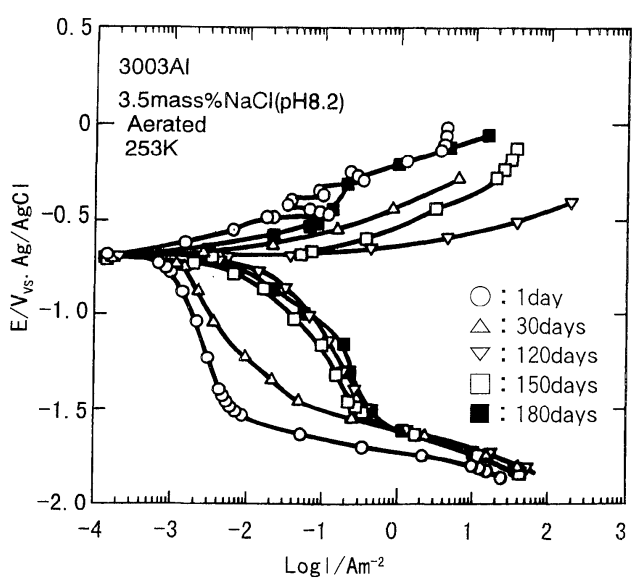

Fig. 6 Effect of immersion time on polarization curve of $\mathrm{A} 3003$ in aerated 3.5 mass $\% \mathrm{NaCl}$ $(\mathrm{pH} 8.2)$ at $253 \mathrm{~K}$.

では水素発生にともなう電流増加が観察された。この停 滞電流は, 21 日後に最大値の約 $3 \times 10^{-1} \mathrm{~A} \cdot \mathrm{m}^{-2}$ の值を 示し, 時間経過とともに電流密度が低下し, 56 日後で は $8 \times 10^{-2} \mathrm{~A} \cdot \mathrm{m}^{-2}$ 程度の值を示した。

試験温度 $253 \mathrm{~K}$ (Fig. 6) では, 腐食電位は-0.7 V 付近で浸漬期間中変化は認められなかった。アノード分 極曲線は浸漬直後では緩やかに增加しているが, 浸漬期 間の経過とともに電流密度の増加傾向が大きくなり, 120 日後に最も増加傾向が大きくなり, その後, その傾 向が緩やかになった。カソード分極曲線は腐食電位から 約 $1.4 \mathrm{~V}$ は停滞電流が観察され, その電位以降では他 の試験温度と同様にプロトンの還元電流が流れている。 この停滞電流密度は浸漬直後では約 $2 \times 10^{-3} \mathrm{~A} \cdot \mathrm{m}^{-2}$ で あったが，浸漬時間の経過とともに増加し約 $1 \times 10^{-1} \mathrm{~A}$ 
・ $\mathrm{m}^{-2}$ の電流密度となった。停滞電流が溶存酸素の拡散 限界電流である場合は密閉系であるため, 浸漬時間とも に溶存酸素は減少し, カソード電流密度は低下すると考 えられる。実際はカソード電流密度が増加していること から, 現在のところ確認されていないが, 別の還元反応 が起こっている可能性が考えられる。

各温度における分極挙動から, $273 \mathrm{~K} \sim 293 \mathrm{~K}$ ではア ルミニウム合金の腐食反応はカソード反応律速であり, $253 \mathrm{~K}$ の凍結環境ではアノード反応も抑制されているこ とから混合律速の可能性もある。

各温度のカソード分極曲線が定常状態の場合の停滞電 流密度と腐食質量減から求めた腐食電流密度の比較を 行った。Fig. 7 に試験温度と腐食電流密度との関係を 示す。ただし, 腐食質量減から算出する腐食電流密度は $\mathrm{Al}$ が $\mathrm{Al}^{3+}$ として溶出することを前提として (3) 式か ら求めた。

$$
\begin{aligned}
& \mathrm{Al} \longrightarrow \mathrm{Al}^{3+}+3 \mathrm{e}^{-} \\
& i=Q / t \cdot S, Q=C \cdot W \cdot n / M
\end{aligned}
$$

$1.0 \times 10^{-5} \mathrm{~A} \cdot \mathrm{m}^{-2}=80.6 \mathrm{~g} \cdot \mathrm{m}^{-2} \cdot \mathrm{d}^{-1}$

ここで $Q$ : 電気量, $t$ : 試験時間, $S:$ 試験面積, $C$ : ファラデー量, $W$ : 質量, $M$ : 原子量, $n$ : 価数とする。

腐食質量減から腐食電流密度を算出すると $293 \mathrm{~K}$ で は $i_{\text {corr }}=5.83 \times 10^{-2} \mathrm{~A} \cdot \mathrm{m}^{-2}, 273 \mathrm{~K}$ では $i_{\text {corr }}=1.61 \times$ $10^{-3} \mathrm{~A} \cdot \mathrm{m}^{-2}$ および $253 \mathrm{~K}$ では $i_{\text {corr }}=3.08 \times 10^{-2} \mathrm{~A} \cdot \mathrm{m}^{-2}$ となる。なお, Fig. 7 中には4. 1項で試験した全温度で の腐食電流密度を図示している。

Fig. 7 に示すように各温度での定常状態における分 極曲線から求めた腐食電流密度と腐食質量減から求めた 腐食電流密度とを比較すると, 分極曲線から求めた腐食 電流密度の方が, 腐食質量減から算出した腐食電流密度

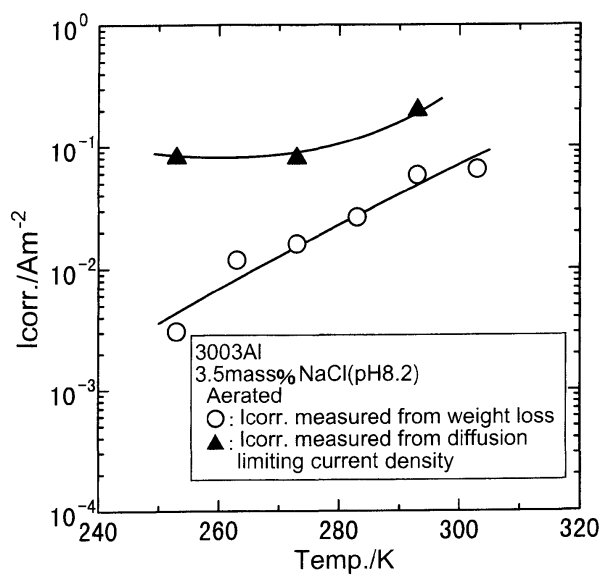

Fig. 7 Comparison of corrosion rate measured from diffusion limiting current density of stationary state with corrosion rate measured from weight loss.
よりも高い電流密度であり, 特に凍結温度域に近くなる 程その差が大きくなることから, 分極曲線を用いて凍結 温度での腐食速度を評価することは困難である。すなわ ち, 凍結環境下では腐食質量減から求めた腐食電流密度 に比べて約 1 桁以上の高い電流がカソード電流として流 れていることから, 前述したように, 溶存酸素の還元電 流のほかに, 別の還元反応が起こっている可能性が示唆 される。

\section{3 インピーダンスの経時変化}

各試験温度 $303 \mathrm{~K}$ および $253 \mathrm{~K}$ におけるインピーダン ス特性を Fig. 8 および 9 に示す。

試験温度 $303 \mathrm{~K}$ (Fig. 8) では, 周波数が約 $10^{-1}$ $10^{\circ} \mathrm{Hz}$ の範囲でインピーダンス $(Z)$ は水平線を示し, $10^{0} \sim 10^{3} \mathrm{~Hz}$ の範囲で傾きー 1 の直線となり, $10^{3} \mathrm{~Hz}$ 以上の周波数では再びインピーダンスが水平となる。 $10^{0} \sim 10^{3} \mathrm{~Hz}$ の傾きは浸漬初期では傾き -1 の勾配であ るが浸漬期間とともに徐々に緩やかなる傾向が認められ た。一方, 位相差 $(\theta)$ は低周波数側で 0 となり, $10^{1}$ $\sim 10^{2} \mathrm{~Hz}$ で-90 付近まで低下し, $10^{2} \mathrm{~Hz}$ 以上の高周 波側では位相差は 0 に戻る。すなわち, 位相差が $10^{-1} \sim$ $10^{6} \mathrm{~Hz}$ の範囲では谷が 1 つであり, 浸漬期間中は試料 表面に水溶液中で形成された腐食生成皮膜の構造に变化 はないものと判断される。

試験温度 $253 \mathrm{~K}$ (Fig. 9) のインピーダンスの変化傾 向は $303 \mathrm{~K}$ の場合と同様であり, 位相差も $303 \mathrm{~K}$ と同 様に低周波領域では位相差が 0 に収束し, 最小で約

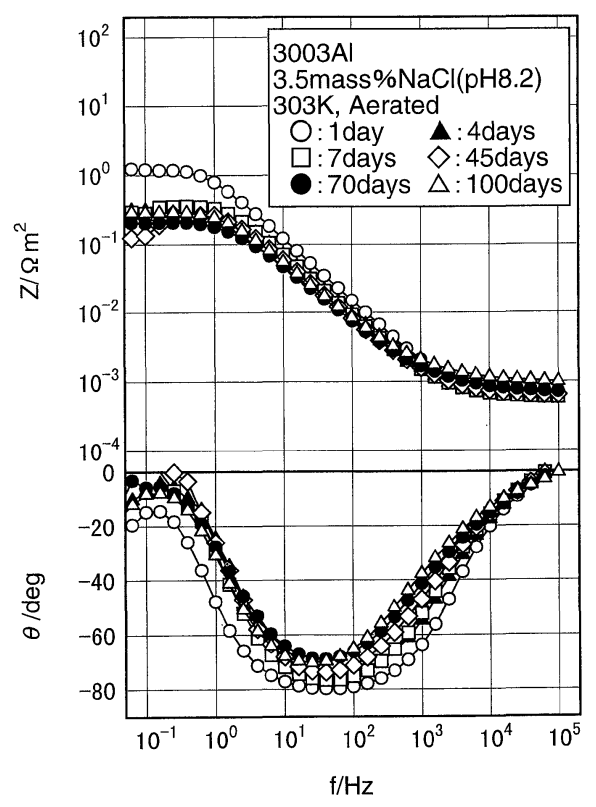

Fig. 8 Time variation of bode diagrams on $3003 \mathrm{Al}$ at $303 \mathrm{~K}$. 


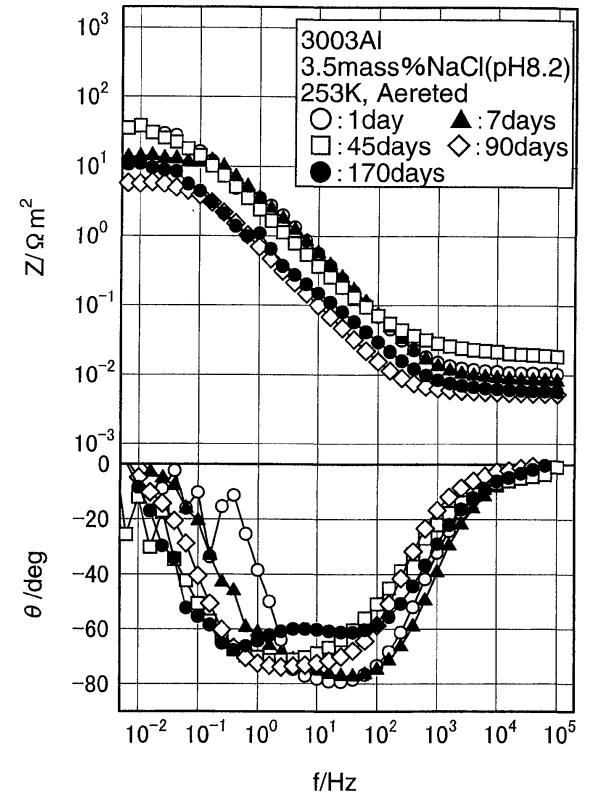

Fig. 9 Time variation of bode diagrams on $3003 \mathrm{Al}$ at $253 \mathrm{~K}$.

-90 まで位相差が低下するが, 浸漬期間とともに大き くなる傾向が認められ，位相差の谷が 1 つから 2 つに変 化しているので, 試料表面に形成された腐食生成物の構 造が変化しているものと判断される。試験温度 $273 \mathrm{~K}$ のインピーダンスの変化傾向も $303 \mathrm{~K}$ の場合と同様の 傾向を示した。

次に腐食速度について検討する。交流インピーダンス 法による腐食抵抗值 $\left(R_{\mathrm{c}}\right)$ の測定は位相差が 0 に収束 する場合の $R_{f \rightarrow 0}$ から溶液抵抗 $R_{\text {sol. }}$ （高周波数域のイ ンピーダンス）を引いた值であると定義される ${ }^{8)}$ が, $R_{f \rightarrow 0} \gg R_{\text {sol. }}$. であるため, $R_{f \rightarrow 0}$ を求めれば腐食抵抗值 が求められる。したがって, 位相差 0 の時の值が $R_{f \rightarrow 0}$ $=R_{\mathrm{c}}$ となる。

試験温度 $303 \mathrm{~K}, 273 \mathrm{~K}$ および $253 \mathrm{~K}$ における腐食抵 抗值の変化を Fig.10 に示す。

試験温度 $303 \mathrm{~K}$ の場合, 浸漬直後の $R_{\mathrm{c}}$ 值は $10^{\circ} \Omega$ ・ $\mathrm{m}^{2}$ のオーダーであるが, 直ちに小さくなり $10^{-1} \Omega \cdot \mathrm{m}^{2}$ オーダーで一定となる。 $273 \mathrm{~K}$ でも同様の傾向を示し, 浸漬直後は $10^{1} \Omega \cdot \mathrm{m}^{2}$ オーダーで直ちに $1 \times 10^{0} \Omega \cdot \mathrm{m}^{2}$ まで低下するが，すぐに $2 \times 10^{0} \Omega \cdot \mathrm{m}^{2}$ で一定となる。 $253 \mathrm{~K}$ の場合も浸漬直後では $10^{2} \Omega \cdot \mathrm{m}^{2}$ オーダーである が浸漬直後に低下し，また，浸漬時間とともに増減しな がら約 $10^{1} \Omega \cdot \mathrm{m}^{2}$ オーダーで一定となった。

また, いずれの試験温度においても, 浸漬直後はこの 腐食抵抗值が大きい值を示しているが, 直ちに腐食抵抗 值が低下している。これは, 浸漬試験前に生成した大気

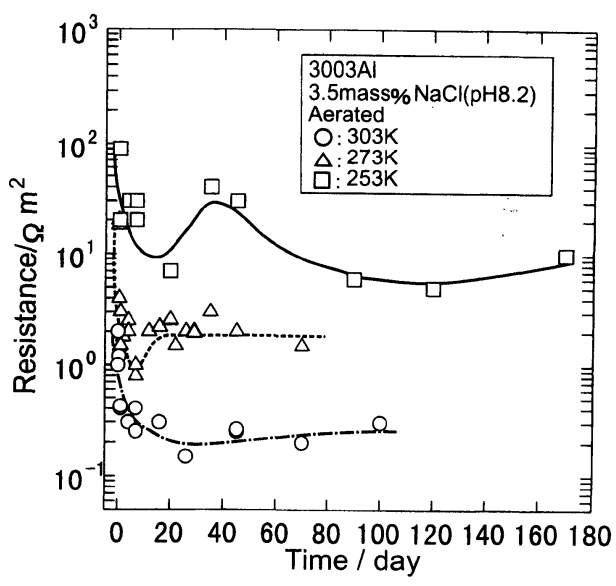

Fig. 10 Time variation of resistance obtained from ac impedance method.

酸化皮膜が無定形で密着性の良い, 緻密な皮膜であり, 保護性の高い皮膜であるが，水溶液に浸漬することによ り皮膜が水和されて結晶化し保護性の低い皮膜になるこ と ${ }^{9)}$ に対応しているものと推察される。

腐食系の交流インピーダンスは春山ら ${ }^{6)}$ により腐食系 を形成する反応が電荷移動に律速されるあるいは拡散が 関与する場合は

$$
i_{\text {corr }}=\frac{1}{m^{\prime} \phi R_{\mathrm{c}}}
$$

となるとされている。

ここで, $\phi=F / R T$ であり, $m^{\prime}$ 值を 2.0 と仮定 ${ }^{6)}$ し, Fig.10 から $253 \mathrm{~K}$ での $R_{\mathrm{c}}=1.0 \times 10^{1} \Omega \cdot \mathrm{m}^{2}, 273$ $\mathrm{K}$ での $R_{\mathrm{c}}=2.1 \times 10^{\circ} \Omega \cdot \mathrm{m}^{2}$ および $303 \mathrm{~K}$ での $R_{\mathrm{c}}=$ $2.7 \times 10^{-1} \Omega \cdot \mathrm{m}^{2}$ であるので, (4) 式を用いて各温度での 腐食速度を算出すると $253 \mathrm{~K}$ での $i_{\text {corr }}=1.1 \times 10^{-3} \mathrm{~A}$ ・ $\mathrm{m}^{-2}, \quad 273 \mathrm{~K}$ での $i_{\text {corr }}=5.6 \times 10^{-3} \mathrm{~A} \cdot \mathrm{m}^{-2}$ および $303 \mathrm{~K}$ では $i_{\text {corr }}=4.8 \times 10^{-2} \mathrm{~A} \cdot \mathrm{m}^{-2}$ となる。これら交流イン ピーダンス測定から求めた腐食速度と腐食質量減から求 めた腐食速度を比較するために Fig. 11 に各温度におけ る両者の腐食速度（ただし， $m^{\prime}=1.5$ での計算值を合わ せて示す）を示す。

Fig. 11 に示すように交流インピーダンス測定から算 出した腐食速度と腐食質量減から求めた腐食速度は良く 一致しており, 特に腐食速度が著しく小さい凍結環境下 でも測定できることが確認された。したがって, 交流イ ンピーダンス法を用いることにより実機での腐食速度の 測定が可能であると考えられる。また, 前述したように, インピーダンス特性は経時的にほとんど変化けないこと が確認されているため, 実機の腐食速度を求齐るための 交流インピーダンス測定は低周波側の領域のみの $R_{\mathrm{sol}}$ $+R_{\mathrm{c}}\left(R_{\mathrm{c}} \gg R_{\mathrm{sol}}\right)$ を測定すれば良く, 短時間の測定も可 能であると考えられる。 


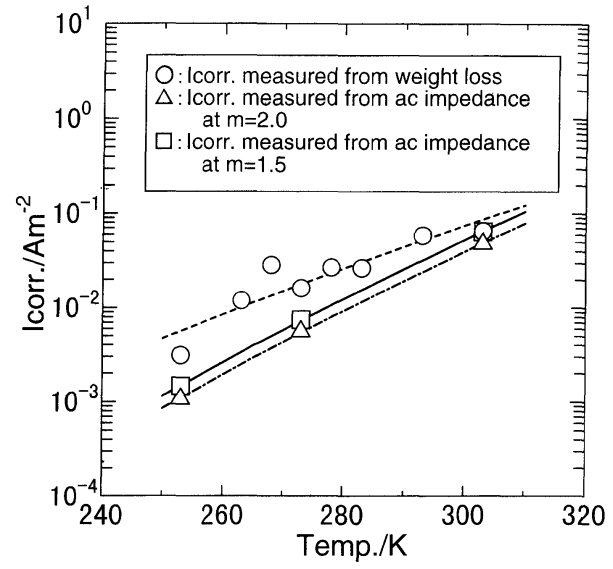

Fig. 11 Comparison of corrosion rate measured from ac impedance with corrosion rate measured from weight loss.

\section{5. 結言}

低温食塩水におけるアルミニウム合金の腐食挙動を検 討した結果，次のことが分かった。

（1） $253 \mathrm{~K}$ のように試験溶液が凍結する場合の腐食 質量減は非常に小さいが, $273 \mathrm{~K}$ 付近では直線的に腐食 質量減が増加し, さらに常温付近では浸漬直後の腐食質 量減が大きく, 時間の経過とともに腐食質量減の増加が 抑制される傾向を示した。

（2） 2 種類の内部照合電極を製作し, 凍結環境下で の使用可能性を検討した結果, 内部照合電極として溶融 $\mathrm{Ag} / \mathrm{AgCl}$ 電極を使用した方が, 電解 $\mathrm{Ag} / \mathrm{AgCl}$ 電極を 使用した場合よりも冷却昇温による温度変化に対する外 部照合電極との電位差変化の再現性の良いことから, 溶 融 $\mathrm{AgCl}$ 電極は凍結環境で使用可能であることがわ かった。
（3）常温から $273 \mathrm{~K}$ 付近までの分極特性はカソード 反応律速であり，凍結温度域では混合支配の可能性が考 えられた。凍結環境下におけるカソード分極曲線上の停 帯電流は浸漬期間とともに増加しているため, 溶存酸素 の還元電流密度とは別の反応も起こっている可能性が示 唆された。

（4）交流インピーダンス法による腐食特性は測定温 度による相違がほとんど認められず, 経時的な変化もほ とんどないことがわかった。また，この方法を用いて算 出した腐食速度と腐食質量減から算出した腐食速度とは よく一致しており，特に腐食速度が著しく小さい凍結環 境でも測定できることがわかった。

（5）したがって，交流インピーダンス法を用いるこ とにより実機での腐食速度の測定が可能であることが示 唆された。

(Manuscript received May 25, 1998; in final form August 14, 1998)

\section{参 考 文 献}

1）塚本彰夫 : R \& D 神戸製鋼技報，27，93（1977）.

2 ）林 浩一, 梶原修三, 藤原和雄, 高谷泰之, 稲葉 光晴 : R\&D 神戸製鋼技報，41，111（1991）.

3 ）海部昌治：軽金属シンポジウム“アルミニウムの 腐食とその防止”, p. 42 (1976).

4 ）舛形 剛, 藤原和雄, 梶原修三, 林 浩一, 高谷 泰之, 稲葉光晴 : 材料, 43 [494］1422（1994）.

5 ) 高谷泰之, 舛形 剛, 藤原和雄, 新開光一, 林 浩一：材料と環境, 47, 254 (1998).

6 ）春山志郎，水流 徹，阿南正治 : 防食技術， 27, 449 (1978).

7 ）水流 徹, 春山志郎：日本金属学会誌，41，306 (1977).

8 ）水流 徹, 春山志郎：防食技術, 28, 134 (1979).

9 ）伊藤伍郎：軽金属，31，683 (1981). 